\title{
Population-specific wintering distributions of adult south polar skuas over three oceans
}

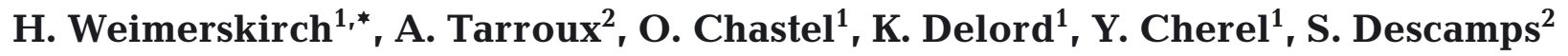 \\ ${ }^{1}$ Centre d'Etudes Biologiques de Chizé, UMR 7372 du CNRS-Université de La Rochelle, 79360 Villiers-en-Bois, France \\ ${ }^{2}$ Norwegian Polar Institute, Fram Centre, 9296 Tromsø, Norway
}

\begin{abstract}
Migratory routes and the areas used during winter have probably been selected to maximize fitness by providing favorable environmental conditions outside the breeding season. In polar environments, because of the extreme winter weather, most breeding species migrate to encounter better conditions in areas that can differ between and also within species. Using geolocation sensors, we found that south polar skuas Catharacta maccormicki from 2 distant populations breeding on the Antarctic continent along the Atlantic and Indian Oceans migrate northward to winter in tropical Indian Ocean and in temperate North Pacific waters, respectively. Most individuals from each population winter in different environmental conditions, with water temperatures ranging from 16 to $29^{\circ} \mathrm{C}$. Nevertheless, they have very similar activity patterns, spending more than $80 \%$ of their time on the water, and their feather $\delta^{15} \mathrm{~N}$ values suggest that they probably feed at similar trophic levels during the molt. During overwintering, the overall and constant low activity level may be partly imposed by molting constraints, but it also suggests that trophic conditions are good for skuas. The wintering areas of the species correspond to sectors of high concentrations of breeding or wintering tropical, Northern, and Southern Hemisphere seabird species that are likely to be kleptoparasitized by skuas. A certain degree of individual variation exists within each population, which induces a spatial overlap in the wintering grounds of distant breeding populations. These results have potential important consequences in terms of fitness, genetic divergence, and susceptibility to climate change and marine pollution.
\end{abstract}

KEY WORDS: Catharacta maccormicki · Geolocators · Migration · Population-specific strategies · Stable isotopes

Resale or republication not permitted without written consent of the publisher

\section{INTRODUCTION}

Migratory behavior is considered to be driven by environmental changes during and outside the breeding season such that during the non-breeding season, individuals migrate to find more favorable conditions at sites often located far from those where breeding occurs (Alerstam \& Lindström 1990, Alerstam 2011). This is particularly relevant for most birds breeding during the short polar summer that migrate to temperate or tropical environments, with some species undergoing trans-equatorial migration and wintering in the opposite hemisphere to take advantage of a second summer season (Alerstam et al. 1993). Among these trans-equatorial migrating species are several seabirds, especially Procellariiformes, that follow the longest migration routes on earth (Shaffer et al. 2006, Egevang et al. 2010). During migration, they use specific routes to take advantage of the oceanic wind regimes (Felicísimo et al. 2008).

South polar skuas Catharacta maccormicki (hereafter SPS) are long-lived seabirds that breed in coastal Antarctica and sometimes inland. During the austral summer, they feed on eggs and chicks of penguins, on other seabirds, or marine mammals, scavenge on land, at sea, or in the pack-ice, and can also 
forage for fish or krill at sea (Furness 1987, Olsen \& Larsson 1997). Breeding grounds are abandoned during the inter-nesting period. Visual observations and ring recoveries showed that juveniles and immatures are long-distance migrants, some performing among the longest known migrations of any bird between the breeding and wintering grounds (Furness 1987, Olsen \& Larsson 1997). In contrast, adult birds were presumed to winter in the pack-ice of the Southern Ocean, probably close to their breeding grounds (Furness 1987, Olsen \& Larsson 1997). This traditional view was recently challenged by the tracking of adults from a population located in the Antarctic Peninsula, with birds migrating to the northern Atlantic and Pacific Oceans, where they winter in temperate waters (Kopp et al. 2011).

SPS have breeding areas that are discretely distributed all around Antarctica, and the wintering areas of the different populations are unknown except for 1 population (Kopp et al. 2011). Hence, determining the wintering areas of birds breeding in distant localities of the Southern Ocean is of particular interest, since northern migration routes could bring different populations either to contrasted environments if individuals simply head north, or to common oceanic sectors shared by all populations. The results have potential important implications in terms of population structure, dynamics, and genetics since spatial segregation during the non-breeding period may reflect genetic divergence (Friesen et al. 2007, Rayner et al. 2011).

Here, we studied the migratory behavior of 2 populations of SPS (Dronning Maud Land and Terre Adélie) breeding $4000 \mathrm{~km}$ apart along the Antarctic continent. Birds were equipped with miniaturized geolocators (global location sensors, GLS) to delineate their non-breeding distribution at sea (Shaffer et al. 2006), and feathers were collected to examine the birds' isotopic niche (as a proxy of the trophic niche) on the molting (non-breeding) grounds (Cherel et al. 2000, Newsome et al. 2007). Moreover, GLS data from the third population breeding on the Antarctic Peninsula (Kopp et al. 2011) were used to map the routes and wintering areas of birds breeding within the 3 major oceans to examine whether adults' winter behavior reflects population-specific migratory strategies.

\section{MATERIALS AND METHODS}

SPS breeding adults were tracked from Svarthamaren, a nunatak located $200 \mathrm{~km}$ inland in Dronning Maud Land $\left(72^{\circ} \mathrm{S}, 5^{\circ} \mathrm{E}\right)$, and from the Pointe Géologie
Archipelago, Terre Adélie $\left(66^{\circ} \mathrm{S}, 140^{\circ} \mathrm{E}\right)$. Between 2007 and 2012, 49 SPS were equipped with GLS light-immersion loggers (British Antarctic Survey). GLS were fixed with cable-ties to a plastic leg band. Birds were equipped when on their nest, and the devices were retrieved after 1 or 2 yr. SPS weigh between 1000 and $1700 \mathrm{~g}$, so that the total mass of devices ( $2 \mathrm{~g}$ ) was always far below the recommended $3 \%$ threshold (Phillips et al. 2003). A total of 13 and 36 birds were tracked from Svarthamaren and Terre Adélie, respectively, with 4 Terre Adélie birds and 2 birds at Svarthamaren tracked over 2 successive seasons. GLS loggers record sunrise/sunset, thus allowing the calculation of latitude and longitude except during 2 to $3 \mathrm{wk}$ around the equinoxes, when only an estimation of longitude is reliable. GLS light data were analyzed following Afanasyev (2004), Phillips et al. (2004), and Egevang et al. (2010) to estimate locational information accurate to $170 \mathrm{~km}$ on average. As positions obtained from GLS have a relatively low accuracy, we used a conservative approach to filter data with maximum speeds and to calculate distance covered. Daily speeds higher than $40 \mathrm{~km} \mathrm{~h}^{-1}$ were excluded since birds spend on average $>80 \%$ of time sitting on water (see 'Results'). In addition to light levels, GLS loggers recorded salt water immersion, allowing the estimation of time spent in flight or sitting on the water. The raw immersion data values ranged from 0 (no immersion) to 200 (permanently immersed), indicating the number of $3 \mathrm{~s}$ periods during 10 min blocks when the sensor was immersed in saltwater. Immersion data were used to estimate the daily percentage of time spent on the sea surface (activity) separately for diurnal and nocturnal periods (based on local sunset and sunrise times derived by analysis of the daylight curves processed using the BASTrak software package). The mean percentage of time spent on the water (wet) was calculated daily during each period of phenology (breeding and interbreeding) to provide information on seasonal variations in foraging behavior. Conversely, the time spent dry is generally interpreted as a bird being either on land at the colony or flying, and therefore could be assumed not to be foraging but traveling, at least during the non-breeding season. The duration of daylight and darkness each day (consecutive light and dark period) was assessed directly from the logger daylight data. GLS also recorded sea surface temperature (SST) (sensor range: -20 to $60^{\circ} \mathrm{C}$ ) when the logger was immersed for at least $10 \mathrm{~min}$. The average SST recorded in July was used as an indicator of the water masses where the birds foraged in the middle of the wintering period. 
Following Jaeger et al. (2009), carbon and nitrogen stable isotope ratios $\left(\delta^{13} \mathrm{C}\right.$ and $\left.\delta^{15} \mathrm{~N}\right)$ were measured on 4 different body back feathers that were collected upon recapture of each individual, thus corresponding to the previous molting period at sea recorded by the GLS. In seabirds, including SPS, feather isotope values represent the foraging habitat $\left(\delta^{13} \mathrm{C}\right)$ and diet/ trophic position $\left(\delta^{15} \mathrm{~N}\right)$ during the non-breeding period because adult birds replace their plumage at that time (Higgins \& Davies 1996, Cherel et al. 2008). Feather preparation and isotopic analyses were detailed by Jaeger et al. (2009). In brief, feathers were cleaned using a 2:1 chloroform:methanol solution and then oven-dried for $48 \mathrm{~h}$ at $50^{\circ} \mathrm{C}$. Every single whole feather was homogenized by cutting it with scissors into small fragments, and a subsample of $\sim 0.3 \mathrm{mg}$ was packed into tin containers for stable isotope analysis. The relative abundance of carbon and nitrogen isotopes were determined with a continuous flow mass spectrometer (Thermo Scientific Delta V Advantage) coupled to an elemental analyzer (Thermo Scientific Flash EA 1112). Results are presented in the usual $\delta$ notation relative to Vienna PeeDee Belemnite and atmospheric $\mathrm{N}_{2}$ for $\delta^{13} \mathrm{C}$ and $\delta^{15} \mathrm{~N}$, respectively. Replicate measurements of internal laboratory standards (acetanilide) indicated measurement errors $<0.15 \%$ for both $\delta^{13} \mathrm{C}$ and $\delta^{15} \mathrm{~N}$ values.

To assign feather signatures to sites, we first looked at the GLS tracks of birds that wintered in only 1 marine area to assign the corresponding feather isotope values to that area. We then carefully examined the feather isotope values of the few birds that wintered in more than 1 area to correctly assign the isotopic values.

Statistical analyses were performed in STATISTICA 12.0. Tests were 2tailed, and the presented values are given as mean \pm SD unless stated otherwise.

\section{RESULTS}

When the breeding season ended in March, adult SPS left the breeding grounds to move northward. All but 1
SPS from Svarthamaren migrated into the tropical Indian Ocean to winter in 3 main areas, namely the Mozambique Channel (SST in July: $22.9 \pm 0.2^{\circ} \mathrm{C}$ ), Seychelles area $\left(28.3 \pm 1.3^{\circ} \mathrm{C}\right)$, and the Bay of Bengal $\left(28.2 \pm 1.2^{\circ} \mathrm{C}\right)$, including coastal Sri Lanka. The remaining bird migrated to the North Atlantic to winter off Newfoundland (Fig. 1). Svarthamaren birds first moved northward with a north-eastern movement in April to stop for several days to weeks $(30 \pm 15 \mathrm{~d}$, range 12-62 d) in 1 or 2 staging areas located in subtropical waters of the southern Indian Ocean, mainly north of the Crozet-Kerguelen Islands; they then headed to their wintering areas in tropical waters in May and June (Fig. 1a,b) where they stayed for $140 \pm$ 21 d (range 110-192 d). Duration of overwintering
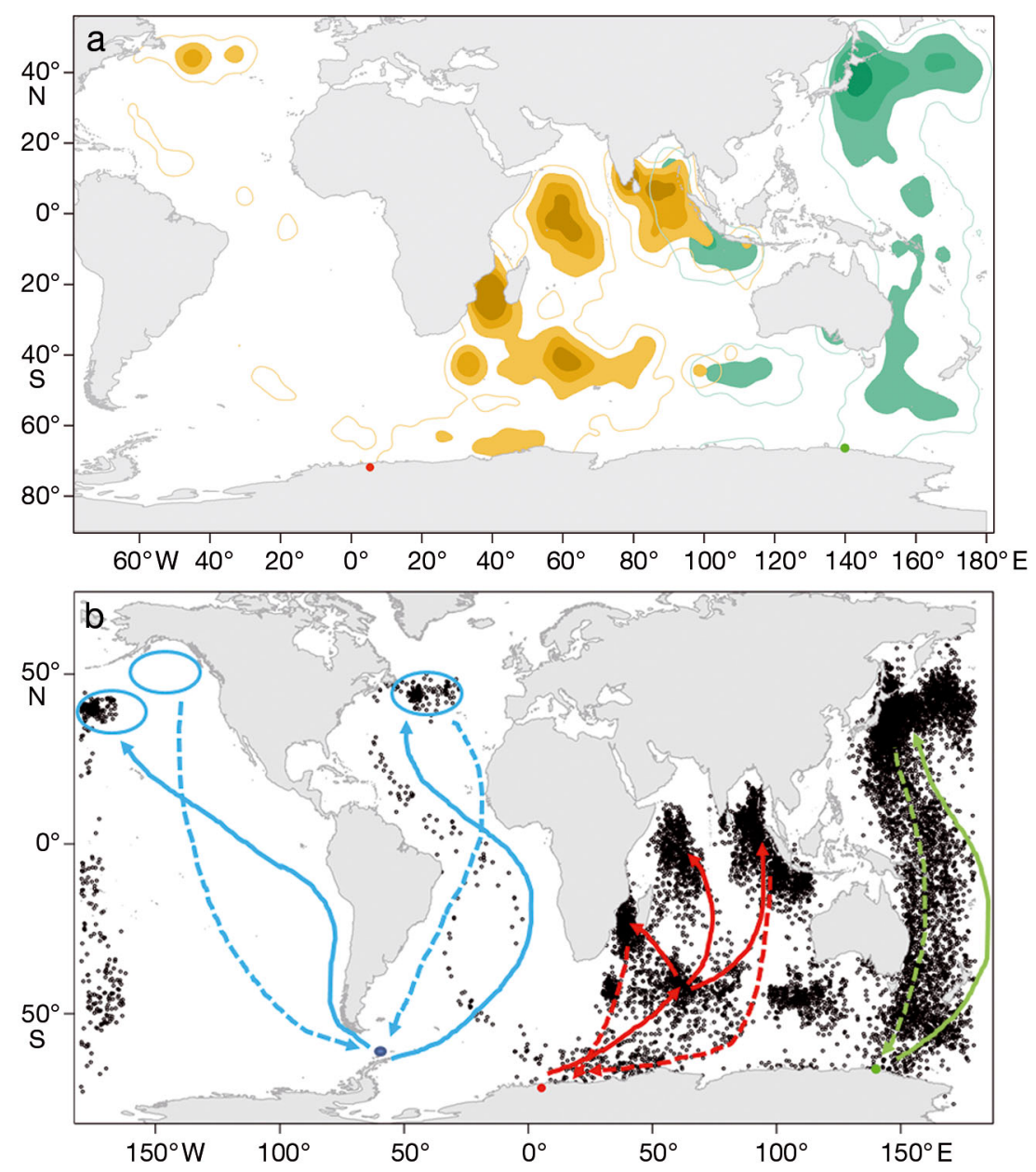

Fig. 1. (a) Kernel densities (utilization densities [UDs]: 25, 50, 75, and 95\%) of non-breeding south polar skuas Catharacta maccormicki from Terre Adélie (green) and Svarthamaren (brown). (b) Locations of tracked south polar skuas showing the routes taken by Terre Adélie birds (green) to winter off Japan, and by Svarthamaren birds (red) wintering in the Indian Ocean. Routes and wintering areas of birds from the Antarctic Peninsula are indicated in blue (Kopp et al. 2011). Continuous and dotted lines depict the outward and return flights to the breeding grounds, respectively 
including the stopover periods lasted $167 \pm 23 \mathrm{~d}$ (138-211 d). The return flights had a southerly direction to the edge of the Antarctic Continent, with birds subsequently flying to the west until reaching the coasts off the colony (Fig. 1b).

In contrast, all but 3 SPS from Terre Adélie migrated directly to the North Pacific, without marked stopovers, to winter off eastern Japan at latitudes of 35 to $45^{\circ} \mathrm{N}$ (Fig. 1), which are characterized by SST averaging $16.7 \pm 0.8^{\circ} \mathrm{C}$ in July. Birds arrived mainly off Japan and progressively shifted eastward in the North Pacific. The total duration of wintering was $141 \pm 19 \mathrm{~d}$ (range 91-190 d), and was much shorter than the total wintering period of Svarthamaren birds wintering in the tropics $\left(F_{1,42}=19.3, \mathrm{p}<0.001\right)$, but was very similar to the wintering period in tropical waters of Svarthamaren birds when excluding the stopovers $\left(F_{1,40}=0.02, \mathrm{p}=0.918\right)$. Of the 3 remaining birds from Terre Adélie, 2 moved to the Bay of Bengal $\left(28.9 \pm 1.1^{\circ} \mathrm{C}\right)$, and 1 wintered in coastal southern Australia $\left(18.0 \pm 2.0^{\circ} \mathrm{C}\right)$. Locations showed that during their trans-equatorial migrations, Terre Adélie birds followed a corridor to move to a well-defined wintering area off eastern Japan. The trans-equatorial migration had a specific pattern, with the northward movement being shifted eastward and the return movement being more direct (Fig. 1). Thus although inter-individual variations exist, most SPS from Svarthamaren wintered in tropical environments, whereas most birds from Terre Adélie wintered in temperate northern waters (Fisher's exact test, $\mathrm{p}<0.01$ ). At the intra-individual level, all 4 SPS from Terre Adélie and the 2 birds from Svarthamaren that were tracked during 2 successive years returned to the same areas each year (3 off eastern Japan, 1 twice in the Bay of Bengal, and 2 off the Seychelles Islands; Fig. 2).

Activity patterns ( $\%$ time spent on the water or in flight) were measured during the migration, stopover, and wintering periods (Fig. 3). Activity patterns varied extensively according to the stage of wintering phase and according to the sector visited (during the day, $F_{7,31}=30.0, \mathrm{p}<0.001$, at night $F_{7,31}=25.4, \mathrm{p}<$ 0.001; Fig. 4). During the outward and return migrations, birds spent 40 to $50 \%$ of their time in flight during the day as well as at night, whereas on the staging and wintering grounds, they spent between 65 and $95 \%$ of their time on the sea surface (Fig. 4). Interestingly, activity patterns differed significantly between the oceanic areas where birds wintered. In the tropics (Bay of Bengal and Seychelles-Somalia sectors) and in the North Pacific off Japan, birds spent most of their time sitting on the water, whereas in the Mozambique

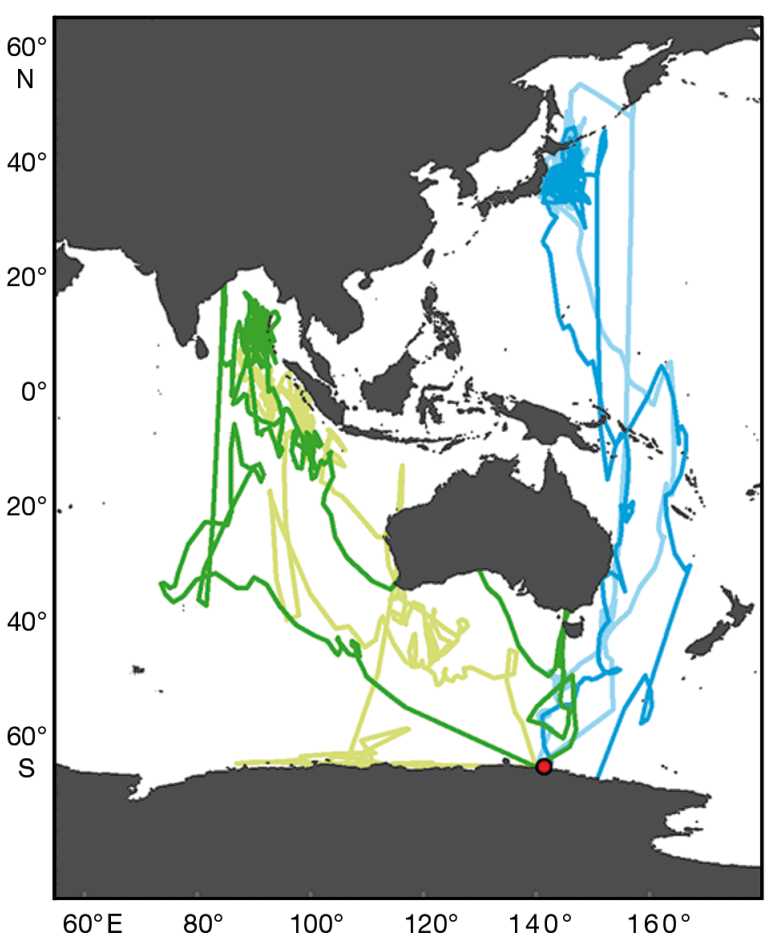

Fig. 2. Migratory movements of 2 South polar skuas Catharacta maccormicki (green and blue) from Terre Adélie during 2 consecutive years (dark and light colour for first and second year, respectively), showing site fidelity to wintering areas from year to year

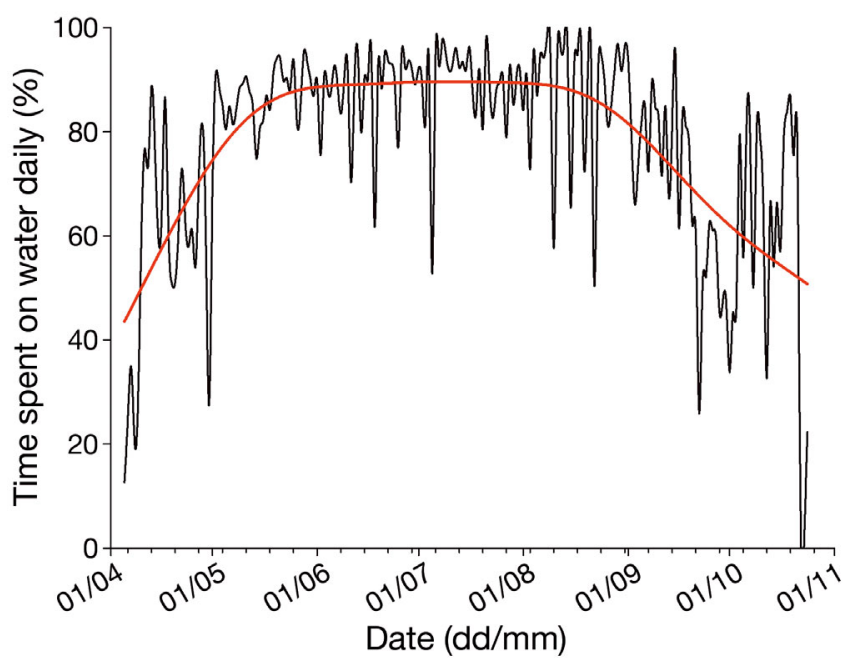

Fig. 3. Activity pattern ( $\%$ of time spent on the water versus time of the year, fitted curve in red) during migration and wintering (when time spent on water attains a plateau) of an individual south polar skua Catharacta maccormicki from Adélie Land in 2009

Channel and in the North Atlantic, birds were more active, spending a significant part of the time in flight, especially during the day (Fig. 4). During wintering, SPS spent the same relative amount of time sitting on the water, although daytime duration was twice as 


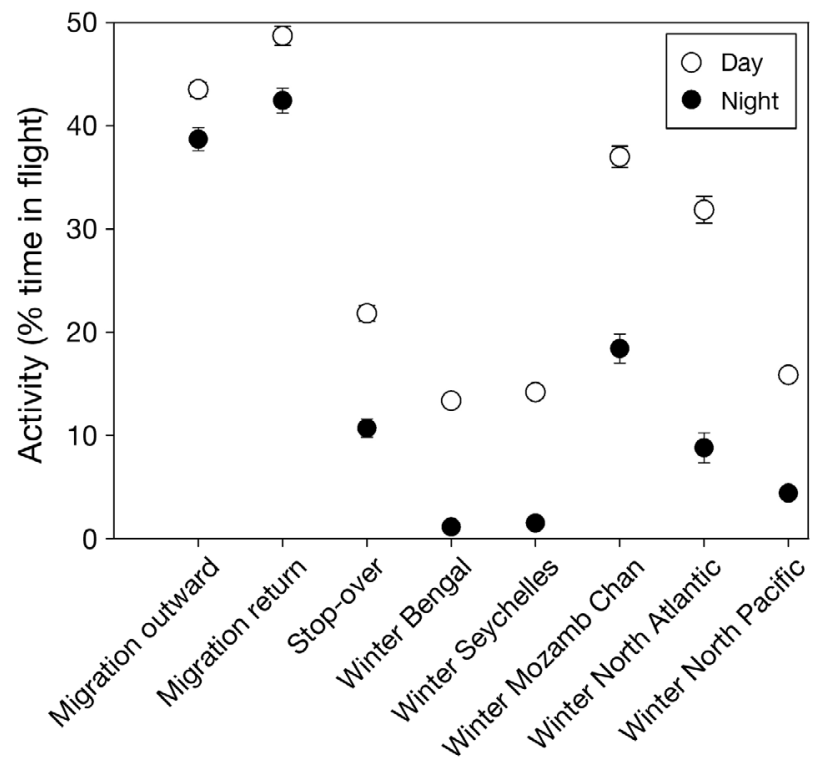

Fig. 4. Mean \pm SE activity pattern ( $\%$ of time spent in flight) during the day (white circles) and at night (black circles) of south polar skuas Catharacta maccormicki from Svarthamaren and Adélie Land during the outward and return phases of migration and on stopovers and wintering grounds in the tropics and the Northern Hemisphere. Wintering grounds are shown in Fig. 1

long for birds wintering in the Northern Hemisphere compared to tropical waters (Fig. 4). On the wintering grounds, birds spent almost the entire night resting on the sea surface, whereas they were slightly more active during the day, although they spent only $20 \%$ of their time in flight (Fig. 4).

A close examination of feather isotopic values with GLS tracks allowed assigning almost all individual feathers to a given molting area (Fig. 1, Table 1). We were unable to reliably assign isotopic signatures to a wintering area for only very few feathers using the described 2step protocol (see 'Unknown' in Table 1). Feather isotopic values indicate that 62.0 and $34.5 \%$ of SPS molted in 1 and 2 different habitats, respectively (Table 1). Only a single bird showed 3 different $\delta^{13} \mathrm{C}$ values among its 4 body feathers, indicating that these feathers grew in 3 distinct isotopic habitats. Feathers from SPS wintering in different areas segregated by their isotopic val- ues (Fig. 5). Within each locality, $\delta^{13} \mathrm{C}$ and $\delta^{15} \mathrm{~N}$ values of feathers molted in different habitats were overall significantly different $\left(\mathrm{ANOVA}_{i}\right.$ Adélie Land: $F_{4,80}=$ 280 and 64, Svarthamaren: $F_{6,51}=913$ and 214 for $\delta^{13} \mathrm{C}$ and $\delta^{15} \mathrm{~N}$, respectively, all $\left.\mathrm{p}<0.0001\right)$. Notably, (1) very few body feathers from a fairly small number of adults birds grew in Antarctic waters, (2) most feathers that were synthesized in different tropical oceanic habitats retained similar isotopic values, (3) the highest $\delta^{13} \mathrm{C}$ and $\delta^{15} \mathrm{~N}$ values were found in a single bird that wintered in coastal Sri Lanka, and (4) the $\delta^{15} \mathrm{~N}$ values corresponding to the staging area in the southern Indian Ocean of Svarthamaren birds were surprisingly low (Table 1, Fig. 5).

\section{DISCUSSION}

Our study indicates that most SPS adults from Svarthamaren and Terre Adélie migrated to different marine habitats and, surprisingly, wintered in very different environmental conditions, namely in tropical and temperate Northern Hemisphere waters, respectively. Not only did the SSTs differ $\left(12^{\circ} \mathrm{C}\right.$ warmer in the tropics), but day length was twice as long at temperate latitudes. However, some birds from both Svarthamaren and Terre Adélie showed different behaviors, thus indicating a significant level of interindividual variability in migratory strategies of SPS at

Table 1. Isotopic niches of south polar skuas Catharacta maccormicki according to various molting areas. Note that some individual birds molted in more than 1 area. Values are means $( \pm \mathrm{SD})$ of all body feathers synthesized within the same habitat. Within each locality, values sharing the same superscript are not significantly different at the 0.05 level (Tukey's honestly significant difference tests)

\begin{tabular}{|lccccc|}
$\begin{array}{l}\text { Localities and } \\
\text { habitats }\end{array}$ & $\begin{array}{c}\text { Individuals } \\
(\mathrm{n})\end{array}$ & $\begin{array}{c}\text { Body } \\
\text { feathers }(\mathrm{n})\end{array}$ & $\begin{array}{c}\text { Feather } \\
\delta^{13} \mathrm{C}(\%)\end{array}$ & $\begin{array}{c}\text { Feather } \\
\delta^{15} \mathrm{~N}(\%)\end{array}$ & $\begin{array}{c}\text { C:N mass } \\
\text { ratio }\end{array}$ \\
\hline $\begin{array}{l}\text { Adélie Land } \\
\text { North Pacific }\end{array}$ & 4 & & & & \\
Japan & 15 & 52 & $-18.0 \pm 0.5^{\mathrm{b}}$ & $12.7 \pm 0.5^{\mathrm{b}}$ & $3.13 \pm 0.01$ \\
East Central Indian & 2 & 6 & $-15.5 \pm 0.3^{\mathrm{c}}$ & $12.9 \pm 0.6^{\mathrm{b}}$ & $3.11 \pm 0.01$ \\
South Australia & 1 & 3 & $-17.2 \pm 0.3^{\mathrm{d}}$ & $14.2 \pm 0.1^{\mathrm{c}}$ & $3.13 \pm 0.01$ \\
Antarctica & 2 & 2 & $-22.0 \pm 0.6$ & $13.1 \pm 0.2$ & $3.11 \pm 0.01$ \\
Unknown & 3 & 4 & - & - & - \\
Chicks (Antarctica) & 11 & 11 & $-22.1 \pm 0.3^{\mathrm{e}}$ & $12.3 \pm 0.5^{\mathrm{b}}$ & $3.12 \pm 0.01$ \\
Svarthamaren & & & & & \\
Mozambique Channel & 3 & 9 & $-16.7 \pm 0.3^{\mathrm{a}}$ & $14.1 \pm 0.3^{\mathrm{a}, \mathrm{b}}$ & $3.14 \pm 0.02$ \\
West Central Indian & 3 & 12 & $-16.1 \pm 0.4^{\mathrm{b}}$ & $13.7 \pm 0.6^{\mathrm{a}, \mathrm{d}}$ & $3.14 \pm 0.04$ \\
East Central Indian & 2 & 6 & $-16.2 \pm 0.3^{\mathrm{a}, \mathrm{b}}$ & $13.5 \pm 0.6^{\mathrm{a}, \mathrm{d}}$ & $3.13 \pm 0.02$ \\
Sri Lanka & 1 & 4 & $-13.8 \pm 0.3^{\mathrm{c}}$ & $14.6 \pm 0.2^{\mathrm{b}}$ & $3.12 \pm 0.01$ \\
South Indian & 3 & 8 & $-18.6 \pm 0.4^{\mathrm{d}}$ & $7.9 \pm 0.5^{\mathrm{c}}$ & $3.14 \pm 0.03$ \\
Antarctica & 1 & 1 & -23.9 & 12.4 & 3.15 \\
North Atlantic & 1 & 4 & $-17.3 \pm 0.4^{\mathrm{e}}$ & $13.0 \pm 0.1^{\mathrm{d}}$ & $3.14 \pm 0.02$ \\
Unknown & 1 & 1 & - & - & - \\
Chicks (Antarctica) & 15 & 15 & $-23.4 \pm 0.3^{\mathrm{f}}$ & $12.1 \pm 0.2^{\mathrm{e}}$ & $3.14 \pm 0.05$ \\
\hline
\end{tabular}




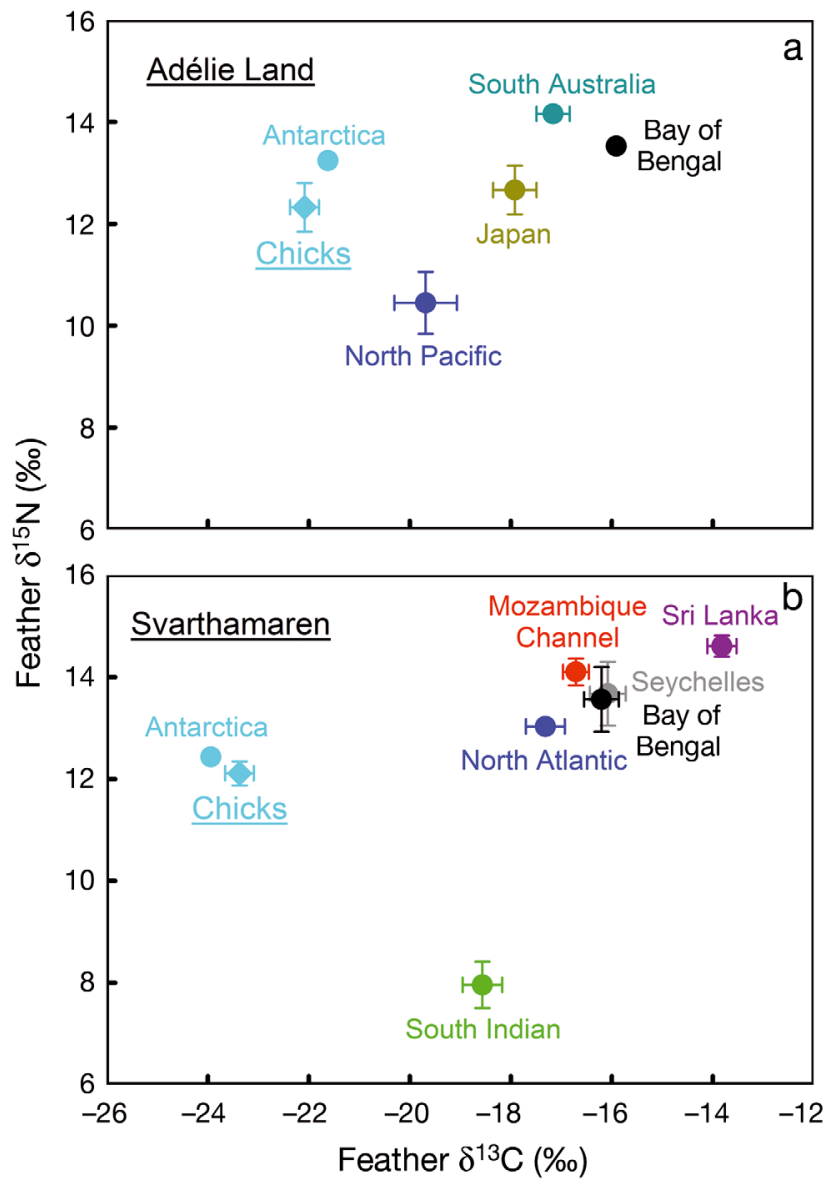

Fig. 5. Body feather $\delta^{15} \mathrm{~N}$ versus $\delta^{13} \mathrm{C}$ values of adults (circles) and chicks (diamonds) of south polar skuas Catharacta maccormicki from (a) Adélie Land and (b) Svarthamaren according to their molting habitats. Values are means $( \pm \mathrm{SD})$ of all body feathers synthesized within the same habitat (Table 1). Chick values are indicative of food brought by parents molting in high-Antarctica $\left(\delta^{13} \mathrm{C}\right)$ and feeding on other seabird eggs and chicks $\left(\delta^{15} \mathrm{~N}\right)$

the population level. Activity patterns in the contrasted tropical and temperate waters were very similar on average, but differed according to oceanic areas within each environment. Birds spent more than $80 \%$ of their time sitting on the water over the entire wintering period in some habitats, while they were more active in others. Yet overall activity level during wintering was low, suggesting strong energetic constraints and/or high food availability.

SPS juveniles and immatures are known as longdistance trans-equatorial migrants, with adult birds expected to winter within the Antarctic pack-ice (Furness 1987, Olsen \& Larsson 1997). The species was regularly recorded in the northern Atlantic and Pacific Oceans, but the populations of origin were unknown, and most SPS off Japan were considered to be immature birds (Furness 1987). Hence, together with Kopp et al. (2011), our study adds substantial information to the wintering biology of the species. As also indicated for the Antarctic Peninsula population (Kopp et al. 2011), our results confirm that no adult SPS remained in the Southern Ocean (south of $40^{\circ} \mathrm{S}$ ) during the non-breeding period. The isotopic data are in agreement with wintering far away from the breeding grounds, since no bird showed the typical very low $\delta^{13} \mathrm{C}$ values that characterize organisms living in high-Antarctic waters (Cherel et al. 2011). Three birds presented a single feather (out of 4) with Antarctic $\delta^{13} \mathrm{C}$ values, thus indicating a partial molt at high latitudes. However, the exact timing of growth of those feathers remains unknown, and it cannot be excluded that they were built up at the end of the breeding season. Although molting during breeding is considered a rare event (Higgins \& Davies 1996), molting of body feathers was observed at Svarthamaren on several individuals.

A second major finding is that birds from 3 distant colonies partition the world's major oceans, with wintering strategies that differ among populations (Fig. 1), although significant variation exists within populations. Breeding adult SPS from the Antarctic Peninsula (Kopp et al. 2011) migrate either to the North Atlantic or to the North Pacific in different geographical areas but similar water masses to those used by Terre Adélie birds (Fig. 1b). Conversely, all but one tracked Svarthamaren birds moved rapidly in a north-eastern direction that brought them into the Indian Ocean where they wintered, instead of heading into the ocean basin directly north of the colony. Thus, by migrating into the Indian Ocean, they cannot move farther north to temperate waters. This suggests that the evolution of migration strategies in trans-equatorial migrating species may be to some extent canalized by the possibilities of access to northern temperate waters. In accordance with this hypothesis, it is interesting to note that whereas SPS moving with a north-eastern flight from Svarthamaren winter in the tropical Indian Ocean, no individual moving with a northern flight heading from the Antarctic Peninsula or Terre Adélie stopped in tropical Pacific or Atlantic sectors. They all crossed tropical areas, or zones of upwelling such as the Benguela or Patagonian shelf sectors that are potentially as favorable as Indian Ocean hot spots, but instead moved directly to the temperate Northern Hemisphere. Interestingly, the duration of the wintering period was similar between birds moving in the Northern Hemisphere and those staying in the tropical Indian Ocean, whereas the route to reach the 
former area is much longer than the latter. This is explained by the specific behavior of birds moving to the tropics whereby they make stop-overs, whereas birds moving to the Northern Hemisphere do not stop en route.

A last relevant finding is that partitioning of the world's oceans is not absolute, with some SPS deviating from the wintering behavior of their population of origin. Two birds from Terre Adélie migrated northwest to the tropical Indian Ocean, as Svarthamaren birds did, and 1 bird from Svarthamaren wintered in the North Atlantic, as some of the Antarctic Peninsula SPS did (Kopp et al. 2011). This intra-population variability in migratory strategies could be explained by the presence of birds of different origins within a given population. The hypothesis is suggested by the important exchanges of SPS between breeding sites as indicated by band re-sightings, e.g. Weimerskirch et al. (1985), and as suggested by Kopp et al. (2011) for SPS from the Antarctic Peninsula. Intra-population variability in wintering areas is rare or absent in some seabird species (Thiebot et al. 2011, 2012), but is a common strategy in others (Ramos et al. 2009, Weimerskirch et al. 2015). However, the number of individuals tracked in Svarthamaren is small, and a larger sample size may allow us to verify the variability in this population.

Activity logger data indicate that SPS spend most of their time on the water, day and night, similar to other great skuas (Phillips et al. 2007, Magnusdottir et al. 2014). The almost complete inactivity of SPS at night is not surprising, since most seabirds generally rest at night. However, the fact that SPS spent less than $20 \%$ of their day time in flight in most wintering sites indicates a low level of foraging activity. This could be interpreted as SPS having little difficulty finding food and needing little time in flight. Alternatively, rather than energetic abundance, low activity could be due to the energetic constraints of flight feathers molting (see Gutowsky et al. 2014). There is some evidence that SPS exhibit a rapid flight feather molt, replacing up to 3 feathers at once in 45 to $60 \mathrm{~d}$ (Ginn \& Melville 1983, Olsen \& Larsson 1997), and thus low activity may be the result of the reduced ability of birds to fly. However, daily activity patterns show that although activity is low on average, birds can still be active occasionally (Fig. 3), suggesting that SPS may be mainly staying at the surface because of molting, but may have periods of higher activity to meet their energy requirements.

The feeding tactics of skuas on wintering grounds are poorly known, but the few recorded visual observations indicated SPS chasing other seabirds and robbing their food (Furness 1987). In the tropical Indian Ocean, SPS winter in areas of high densities of seabirds that include the very abundant sooty tern (Le Corre et al. 2012). Farther south, the staging area of Svarthamaren SPS lies in the northern vicinity of the Subtropical Front that is also marked by high densities of seabirds (Delord et al. 2014) and closely matches a recently discovered staging area of migrating Arctic terns (Fijn et al. 2013). Differences in activity patterns between tropical wintering areas, with higher activity in the Mozambique Channel compared to the Seychelles and Bay of Bengal areas, may be related to differences in communities of prey and/or species subject to kleptoparasitism. Similarly, the SPS wintering areas in the northern Atlantic and Pacific Oceans are residence areas for huge numbers of seabirds, including both breeding birds from the Northern Hemisphere and migrants from the Southern Hemisphere. For example, the main wintering area of SPS from Adélie Land corresponds in space and time to the wintering grounds of the super abundant sooty and short-tailed shearwaters in the North Pacific (Shaffer et al. 2006, Carey et al. 2014), and wintering grounds of SPS from the Antarctic Peninsula and of some individuals from Svarthamaren overlap with a well-known hot spot for foraging seabirds (Frederiksen et al. 2012), including migrating sooty shearwaters (Hedd et al. 2012). Again, differences in activity patterns between the North Atlantic and North Pacific may be related to differences in seabird communities.

Together with GLS locations, feather isotopic values indicated that a majority of individual SPS molted in a single habitat. This was exemplified by the similar high $\delta^{13} \mathrm{C}$ and $\delta^{15} \mathrm{~N}$ values of the 4 feathers of the single SPS that wintered off coastal Sri Lanka, which are in agreement with the well-known inshoreoffshore isotopic gradients in the marine environment. $\delta^{15} \mathrm{~N}$ values of feathers that grew in oceanic waters remained elevated overall (10.4-14.1\%o), independent of the population and for all but 1 area (i.e. the South Indian Ocean). In particular, the $\delta^{13} \mathrm{C}$ and $\delta^{15} \mathrm{~N}$ values of feathers from Svarthamaren birds that grew in different oceanic tropical environments (Mozambique Channel, Seychelles, Bay of Bengal) were similar (Table 1). This suggests no major change in the trophic levels of SPS molting in different water masses. Different habitats, and hence different ecosystem $\delta^{15} \mathrm{~N}$ baseline levels, preclude a more precise comparison, but it is likely that Svarthamaren birds that molted in the southern Indian Ocean fed on lower trophic level prey items that remain to be determined $\left(\delta^{15} \mathrm{~N}=7.9 \%\right.$; Fig. 5). Remark- 
ably, feather $\delta^{13} \mathrm{C}$ and $\delta^{15} \mathrm{~N}$ values of SPS that molted in the Mozambique Channel and off eastern Japan were similar to the feather isotopic values recorded for winter-breeding sooty terns from Europa Island (chick values: $-16.6 \pm 0.2$ and $13.7 \pm 0.3 \%$, respectively), and from sooty shearwaters wintering off Japan (adult values: $-18.2 \pm 0.6$ and $12.3 \pm 0.8 \%$ ), respectively (Cherel et al. 2008, Thompson et al. 2015). The isotopic similarity can result from 2 nonexclusive explanations: SPS either feed on the same prey as do terns and shearwaters, or they kleptoparasitize these other seabirds. The foraging ecology at depths of shearwaters (Shaffer et al. 2006) precludes the former explanation, while the latter is supported by observations of SPS chasing shearwaters off Japan (A. Takahashi \& Y. Watanuki pers. comm.) and harassing bridled terns (which are closely related to sooty terns) off Sri Lanka (De Silva 2011). Hence, both the selection of seabird hotspots by wintering SPS and their feather stable isotope signatures concur to suggest a kleptoparasitic way of life of SPS during the non-breeding period. Together with the high range of wintering environments, this feeding strategy emphasizes the high level of foraging plasticity of this species, which is known to use different techniques, including fishing at sea, preying upon seabirds on land, or scavenging on the coast during the breeding season in high-Antarctica (Furness 1987). However, additional direct observations on wintering grounds are necessary to definitely determine whether SPS are mainly kleptoparasitizing other seabirds or feeding at the surface on the same prey as the other seabirds.

Our study has revealed important differences between SPS populations in their wintering behavior, but also some variability within populations. In addition, we showed that individuals seem faithful to their wintering grounds from one year to the next, as has been found in other seabird species in which some variability exists (Quillfeldt et al. 2010). Such a variability between and within populations of the same species should not only have consequences for the evolution of life history traits and for genetic divergence, but also in terms of susceptibility to climate changes. Indeed, the conditions encountered in tropical and in temperate waters are likely to change in the future at different rates, and will thus likely affect populations differently. Moreover, conditions in the different wintering grounds are likely to differ in terms of many other environmental stressors such as contaminants. For example, SPS from Adélie Land winter just off Japan where Fukushima-derived radionuclides have been found in all marine biotas in this area (Buesseler et al. 2012) and in other top predators such as tunas (Madigan et al. 2012). Monitoring of these different populations in relation to wintering conditions would be an important topic of future research in evolutionary ecology in the context of global change.

Acknowledgements. We thank the many field workers involved in the field studies in Terre Adélie and Svarthamaren, in particular R.A Philipps, T. Nordstad, S. Haaland, E. Soininen, J. Swärd, and G. Mabille. We also thank M. Brault-Favrou for the preparation of feather samples and G. Guillou for running stable isotope analysis. The Ethics Committee of IPEV and Comité Environnement Polaire approved the field procedures for Terre Adélie. The Norwegian Animal Research Authority (NARA/FDU) approved the work on SPS at Svarthamaren. The study at Terre Adélie was supported by IPEV (program no. 109), with additional funding from the Prince Albert II de Monaco Foundation and The ANR Polar Top Program. The study at Svarthamaren was funded by the Norwegian Research Council (Norwegian Antarctic Research Expedition program). We thank 3 anonymous referees for extensive comments on an earlier version of the manuscript.

\section{LITERATURE CITED}

Afanasyev V (2004) A miniature daylight level and activity data recorder for tracking animals over long periods. Mem Nat Inst Pol Res (Spec Issue) 58:227-233

Alerstam T (2011) Optimal bird migration revisited. J Ornithol 152:5-23

Alerstam T, Lindström Ã (1990) Optimal bird migration: the relative importance of time, energy, and safety. In: Gwinner E (ed) Bird migration. Springer, Berlin, p 331-351

Alerstam T, Christie D, Ulfstrand A (1993) Bird migration. Cambridge University Press, Cambridge

Buesseler KO, Jayne SR, Fisher NS, Rypina II and others (2012) Fukushima-derived radionuclides in the ocean and biota off Japan. Proc Natl Acad Sci USA 109: 5984-5988

> Carey MJ, Phillips RA, Silk JR, Shaffer SA (2014) Transequatorial migration of short-tailed shearwaters revealed by geolocators. Emu 114:352-359

> Cherel Y, Weimerskirch H, Hobson K (2000) Using stableisotope analysis of feathers to distinguish moulting and breeding origins of seabirds. Oecologia 122:155-162

Cherel Y, Le Corre M, Jaquemet S, Ménard F, Richard P, Weimerskirch H (2008) Resource partitioning within a tropical seabird community: new information from stable isotopes. Mar Ecol Prog Ser 366:281-291

Cherel Y, Koubbi P, Giraldo C, Penot F and others (2011) Isotopic niches of fishes in coastal, neritic and oceanic waters off Adélie Land, Antarctica. Polar Sci 5:286-297

De Silva RI (2011) Observing oceanic birds in Sri Lanka. Indian Birds 7:58-63

Delord K, Barbraud C, Bost CA, Deceuninck B and others (2014) Areas of importance for seabirds tracked from French southern territories, and recommendations for conservation. Mar Policy 48:1-13

Egevang C, Stenhouse IJ, Phillips RA, Petersen A, Fox JW, Silk JR (2010) Tracking of Arctic terns Sterna paradisaea 
reveals longest animal migration. Proc Natl Acad Sci USA 107:2078-2081

Felicísimo Á, Muñoz J, González-Solís J (2008) Ocean surface winds drive dynamics of transoceanic aerial movements. PLoS ONE 3:e2928

Fijn RC, Hiemstra D, Phillips RA, van der Winden J (2013) Arctic terns Sterna paradisaea from The Netherlands migrate record distances across three oceans to Wilkes Land, East Antarctica. Ardea 101:3-12

Frederiksen M, Moe B, Daunt F, Phillips RA and others (2012) Multicolony tracking reveals the winter distribution of a pelagic seabird on an ocean basin scale. Divers Distrib 18:530-542

Friesen VL, Burg TM, McCoy KD (2007) Mechanisms of population differentiation in seabirds. Mol Ecol 16: 1765-1785

Furness RW (1987) The skuas. T \& AD Poyser, Calton

Ginn HB, Melville DS (eds) (1983) Moult in birds. BTO Guide 19. British Trust for Ornithology, Tring

> Gutowsky S, Gutowsky L, Jonsen I, Leonard M, Naughton M, Romano M, Shaffer S (2014) Daily activity budgets reveal a quasi-flightless stage during non-breeding in Hawaiian albatrosses. Mov Ecol 2:23

Hedd A, Montevecchi WA, Otley H, Phillips RA, Fifield DA (2012) Trans-equatorial migration and habitat use by sooty shearwaters Puffinus griseus from the South Atlantic during the nonbreeding season. Mar Ecol Prog Ser 449:277-290

Higgins PJ, Davies SJ (eds) (1996) Handbook of Australian, New Zealand and Antarctic birds. Vol 3, Snipe to pigeons. Oxford University Press, Melbourne

> Jaeger A, Blanchard P, Richard P, Cherel Y (2009) Using carbon and nitrogen isotopic values of body feathers to infer inter-and intra-individual variations of seabird feeding ecology during moult. Mar Biol 156:1233-1244

Kopp M, Peter HU, Mustafa O, Lisovski S, Ritz MS, Phillips RA, Hahn S (2011) South polar skuas from a single breeding population overwinter in different oceans though show similar migration patterns. Mar Ecol Prog Ser 435:263-267

> Le Corre M, Jaeger A, Pinet P, Kappes MA and others (2012) Tracking seabirds to identify potential Marine Protected Areas in the tropical western Indian Ocean. Biol Conserv 156:83-93

Madigan DJ, Baumann Z, Fisher NS (2012) Pacific bluefin tuna transport Fukushima-derived radionuclides from Japan to California. Proc Natl Acad Sci USA 109: 9483-9486

Magnusdottir E, Leat EH, Bourgeon S, Jónsson JE and others (2014) Activity patterns of wintering great skuas Stercorarius skua. Bird Study 61:301-308

Editorial responsibility: Scott Shaffer,

San Jose, California, USA
Newsome SD, Martinez del Rio C, Bearhop S, Phillips DL (2007) A niche for isotopic ecology. Front Ecol Environ 5: 429-436

Olsen KM, Larsson H (1997) Skuas and jaegers: a guide to the skuas and jaegers of the world. Pica Press, Mountfield

Phillips RA, Xavier JC, Croxall JP (2003) Effects of satellite transmitters on albatrosses and petrels. Auk 120: 1082-1090

Phillips RA, Silk JRD, Croxall JP, Afanasyev V, Briggs DR (2004) Accuracy of geolocation estimates for flying seabirds. Mar Ecol Prog Ser 266:265-272

Phillips RA, Catry P, Silk JRD, Bearhop S, McGill R, Afanasyev V, Strange IJ (2007) Movements, winter distribution and activity patterns of Falkland and brown skuas: insights from loggers and isotopes. Mar Ecol Prog Ser 345:281-291

Quillfeldt P, Voigt CC, Masello JF (2010) Plasticity versus repeatability in seabird migratory behaviour. Behav Ecol Sociobiol 64:1157-1164

Ramos R, González-Solís J, Ruiz X (2009) Linking isotopic and migratory patterns in a pelagic seabird. Oecologia 160:97-105

Rayner MJ, Hauber ME, Steeves TE, Lawrence HA and others (2011) Contemporary and historical separation of transequatorial migration between genetically distinct seabird populations. Nat Commun 2:332

> Shaffer SA, Tremblay Y, Weimerskirch H, Scott D and others (2006) Migratory shearwaters integrate oceanic resources across the Pacific Ocean in an endless summer. Proc Natl Acad Sci USA 103:12799-12802

> Thiebot JB, Cherel Y, Trathan PN, Bost CA (2011) Inter-population segregation in the wintering areas of macaroni penguins. Mar Ecol Prog Ser 421:279-290

> Thiebot JB, Cherel Y, Trathan PN, Bost CA (2012) Coexistence of oceanic predators on wintering areas explained by population-scale foraging segregation in space or time. Ecology 93:122-130

Thompson DR, Torres LG, Taylor GA, Rayner MJ and others (2015) Stable isotope values delineate the non-breeding distributions of sooty shearwaters Puffinus griseus in the North Pacific Ocean. Mar Ecol Prog Ser 521:277-282

> Weimerskirch H, Jouventin P, Mougin JC, Stahl JC, VanBeveren M (1985) Banding recoveries and the dispersal of seabirds breeding in French Austral and Antarctic territories. Emu 85:22-33

Weimerskirch H, Delord K, Guitteaud A, Phillips RA, Pinet P (2015) Extreme variation in migration strategies between and within wandering albatross populations during their sabbatical year, and their fitness consequences. Sci Rep 5:8853, doi:10.1038/srep08853

Submitted: March 17, 2015; Accepted: August 18, 2015

Proofs received from author(s): October 12, 2015 